\title{
PERAN GURU PENDIDIKAN PANCASILA DAN KEWARGANEGARAAN DALAM MENGATASI KENAKALAN PESERTA DIDIK
}

\author{
Aryanti Dwi Untari ${ }^{1}$, Nurfitriana ${ }^{2}$ \\ Universitan Banten Jaya \\ Serang, Indonesia \\ aryantidwiuntari@unbaja.ac.id ${ }^{1}$, linamarlina@unbaja.ac.id ${ }^{2}$, Vt75733gmail.com ${ }^{3}$
}

\begin{abstract}
This study aims to find out how the role of pancasila and citizenship education teachers in addressing the delinquency of learners in MTs Al-Khairiyah Kepandean, what are the forms of delinquency of learners in MTs Al-Khairiyah Kepandean and what are the obstacles of teachers pancasila education and citizenship in overcoming mischief students in MTs Al-Khairiyah Kepandean. This research uses qualitative research method, with descriptive approach. Data collection conducted by using interview techniques, observation, and documentation later processed again and examined by using triangulation techniques that aim to check the validity of data. The results of this study illustrate that the role of Pancasila and citizenship education teachers in addressing the delinquency of learners in MTs Al-Khairiyah Kepandean done through the role as a mentor, role as a moral agent, role as communicator and role as model. The forms of delinquency of learners in MTs AlKhairiyah Kepandean are included in a-social and a-moral delinquency and can be categorized into mild mischief. The barriers of Pancasila and citizenship education teachers in dealing with delinquency of students in MTs Al-Khairiyah Kepandean are derived from family factors, environmental factors and schools.
\end{abstract}

Keywords: Teacher Role, Delinquency Learner

\section{PENDAHULUAN}

Pendidikan merupakan pemberian bimbingan atau pimpinan secara sadar oleh pendidik terhadap perkembangan jasmani dan rohani peserta didik menuju terbentuknya kepribadian yang utama (Ahmad D. Marimba dalam Supardi dkk 2010:3). Salah satu yang menjadi komponen penting di dalam sistem pendidikan yaitu dari gurunya itu sendiri. Menurut Undang-Undang Sisdiknas tentang Guru pasal 39 ayat 2 dalam E. Mulyasa 2015: 197 "Pendidik merupakan tenaga profesional yang bertugas merencanakan dan melaksanakan proses pembelajaran, menilai hasil pembelajaran, melakukan pembimbingan dan pelatihan, serta melakukan penelitian dan pengabdian kepada masyarakat, terutama bagi pendidik pada perguruan tinggi. Guru disini sangat memiliki peran yang penting di dalam pendidikan. Sebagaimana yang dikemukaan oleh (E Mulyasa 2015:29) bahwa peran seorang guru adalah: Peran 
guru sebagai pendidik merupakan peran yang berkaitan dengan tugas memberi bantuan dan dorongan (support), tugas pengawasan dan pembinaan (supervisor) serta tugas yang berkaitan dengan mendisiplinkan peserta didik agar patuh terhadap aturan-aturan sekolah dan norma hidup dalam keluarga dan masyarakat. Salah satu mata pelajaran yang berkaitan dengan tingkah laku dan norma-norma ialah mata pelajaran Pendidikan Pancasila dan Kewarganegaraan. Pendidikan pancasila dan kewarganegaraan merupakan mata pelajaran yang digunakan sebagai wahana untuk mengembangkan dan melestarikan nilai luhur dan moral yang berakar pada budaya bangsa Indonesia. Namun akhirakhir ini, moral peserta didik mengalami penurunan. Dapat dilihat dari tingkat kualitas penyimpangan atau kenakalan yang dilakukan oleh peserta didik. Kenakalan peserta didik merupakan suatu perilaku yang menyimpang atau yang melanggar aturan-aruran hukum yang dilakukan individu maupun kelompok dalam lingkungan sekolah dan dapat merugikan diri sendiri dan juga orang lain. Apalagi diusia masa remaja, remaja adalah masa yang labil karena masa remaja merupakan masa peralihan dari kanak-kanak ke dewasa. Perkembangan menuju kedewasaan memerlukan perhatian yang secara sungguh-sungguh. Berdasarkan hasil pengamatan dan wawancara kepada guru Pendidikan Pancasila dan Kewarganegaraan, peneliti melihat perilaku menyimpang dikalangan para peserta didk diantaranya melawan kepada guru, berpakaian tidak sesuai dengan aturan yang berlaku, merokok dilingkungan sekolah, kebut-kebutan di jalan, pacaran, membolos ketika proses KBM berlangsung dan berbohong.

Berdasarkan masalah yang di atas, maka Peneliti merasa tertarik untuk mengadakan penelitian di MTs AlKhairiyah Kepandean Ciruas dengan judul "Peran Guru Pendidikan Pancasila dan Kewarganegaraan dalam Mengatasi Kenakalan Peserta Didik (Studi Deskriptif di MTs Al-Khairiyah Kepandean Kecamatan Ciruas)".

\section{METODE PENELITIAN}

Tempat penelitian dilakukan di MTs Al-Khairiyah Kepandean, yang beralamat di J1. Al. Syarif Kp. Kejaban Desa Kepandean Kecamatan Ciruas Kabupaten Serang-Banten. Adapun untuk waktu penelitian nya itu sendiri dimulai dari tanggal 16 April 2018. Subjek penelitian ini adalah guru Pendidikan Pancasila dan Kewarganegaraan, kepala sekolah, guru Aqidah Akhlaq, wali kelas VIII B, dan 15 
pesera didik MTs Al-Khairiyah Kepandean.

Untuk memperoleh data yang relevan dengan masalah yang diteliti, dilakukan dengan cara sebagai berikut :

1. Wawancara

Wawancara adalah percakapan dengan maksud tertentu. Percakapan itu dilakukan oleh dua pihak yaitu pewawancara (interviewer) yang mengajukan pertanyaan dan pihak yang diwawancarai (interviewee) yang memberikan jawaban atas pertanyaan itu (Moleong, 2014: 186). Wawancara yang digunakan dalam penelitian ini adalah wawancara secara langsung, berupa interview secara mendalam kepada Guru Pendidikan Pancasila dan Kewarganegaraan, peserta didik, kepala sekolah, guru aqidah akhlaq, dan wali kelas VIII B yang ada di MTs Al-Khairiyah Kepandean.

2. Observasi

Cartwright dalam Uhar Suharsaputra (2014: 209) mendefinisikan observasi sebagai suatu proses melihat, mengamati, dan mencermati serta merekam prilaku secara sistematis untuk suatu tujuan tertentu. Dalam pelaksanaan pengumpulan data kali ini, peneliti menggunakan observasi non partisipan sebab peneliti tidak terlibat, hanya sebagai pengamat independen. Namun sebelum melakukan observasi peneliti terlebih dulu membuat pedoman observasi dengan tujuan sebagai acuan untuk proses observasi agar tetap fokus dan tidak keluar dari tujuan utama.

\section{Dokumentasi}

Dokumentasi adalah metode mencari data mengenai hal-hal atau variabel yang berupa catatan, transkip, buku, surat kabar, majalah, agenda, dan sebagainya (Arikunto, 2006: 231). Untuk jenis dokumentasi yang digunakan dalam penelitian ini berupa foto, dan biografi.

Adapun dalam menguji objektivitas dan keabsahan data pada penelitian ini adalah menggunakan teknik trianggulasi. Moleong (2014: 330) mengemukakan bahwa trianggulasi adalah teknik pemeriksaan keabsahan data yang memanfaatkan sesuatu yang lain. Diluar data itu keperluan pengecekan atau sebagai pembanding terhadap data itu. Trianggulasi yang dilakukan dalam penelitian ini adalah triangulasi memanfaatkan sumber dan triangulasi metode.

Metode analisis data adalah proses mengorganisasikan dan mengurutkan data kedalam suatu pola, ketegori dan suatu uraian dasar sehingga dapat ditemukan 
tema dan dapat dirumuskan hipotesis kerja seperti yang disarankan oleh data (Moleong, 2014: 280). Aktivitas dalam penelitian ini yaitu analisis data, reduksi data (data reduction), penyajian data (data display), dan penarikan kesimpulan (conclusion drawing/verification).

\section{HASIL PENELITIAN DAN PEMBAHASAN}

Peran guru Pendidikan Pancasila dan Kewarganegaraan dalam mengatasi kenakalan peserta didik di MTs AlKhairiyah Kepandean yang ditemukan oleh peneliti di lapangan sebagai berikut:

Guru Pendidikan Pancasila dan Kewarganegaraan dalam melaksanakan perannya sebagai pembimbing, mempunyai tugas untuk membantu peserta didik dalam mengatasi kesulitan dalam proses pembelajaran (Hamalik, 2008: 9). Guru Pendidikan Pancasila dan Kewarganegaraan di MTs Al-Khairiyah Kepandean dalam membimbing peserta didik dengan cara memberikan arahanarahan atau nasihat-nasihat, dengan harapan peserta didik untuk selalu menaati aturan yang ada disekolah dan tidak melakukan kenakalan.

Guru sebagai agen moral turut membina moral masyarakat dan peserta didik, serta menunjang upaya-upaya pembangunan (Hamalik, 2008: 9). Guru

Pendidikan Pancasila dan Kewarganegaraan di sekolah MTs AlKhairiyah Kepandean dalam melaksanakan perannya sebagai agen moral, melalui penanaman-penanaman nilai-nilai moral terhadap peserta didik di sekolah MTs Al-Khairiyah Kepandean dengan cara penilaian sikap dan memberikan contoh-contoh langsung kepada peserta didik, misalnya: saling menghargai pendapat orang lain.

Guru Pendidikan Pancasila dan Kewarganegaraan di MTs Al-Khairiyah Kepandean dalam melaksanakan perannya sebagai komunikator, guru Pendidikan Pancasila dan Kewarganegaraan melakukan hubungan komunikasi yang baik dengan peserta didik yang melakukan kenakalan-kenakalan. Guru Pendidikan Pancasila dan Kewarganegaraan berkomunikasi dengan peserta didik yang melakukan kenakalan dengan cara menanyakan terlebih dahulu alasan peserta didik melakukan kenakalan, namun apabila kenakalan peserta didik tersebut terus menerus diulanginya lagi oleh peserta didik maka guru Pendidikan Pancasila dan Kewarganegaraan dengan tegas memberikan surat panggilan pihak orang tua untuk ke sekolah MTs AlKhairiyah Kepandean. Hal ini sejalan dengan teori yang diungkapkan oleh 
Hamalik (2008: 9): Peran guru sebagai komunikator yaitu melakukan komunikasi dengan siswa dan masyarakat.

Peran guru sebagai model, yaitu mampu memberikan contoh yang baik kepada peserta didiknya agar berperilaku yang baik (Hamalik, 2008: 9). Guru Pendidikan Pancasila dan Kewarganegaraan di MTs Al-Khairiyah Kepandean berperan sebagai model dengan cara memberikan suri tauladan yang baik agar dapat ditiru oleh peserta didik, dengan terlebih dahulu guru Pendidikan Pancasila dan Kewarganegaraan memberikan contohnya langsung kepada peserta didik, misalnya guru Pendidikan Pancasila dan Kewarganegaraan selalu memberikan contoh cara berpakaian dengan sesuai aturan, selalu datang ke sekolah dengan tepat waktu, dan berbicara yang sopan.

Kenakalan peserta didik adalah tingkah laku yang dilakukan oleh seorang peserta didik yang bersifat melanggar ketentuan-ketentuan norma-norma atau aturan di lingkungan sekolah. Kenakalan sebagian dari tanda kemerosotan moral peserta didik yang tidak dapat dilepaskan dari unsur sosial, budaya yang ada. Untuk itu masalah ini harus segera diatasi oleh pihak sekolah, agar peserta didik tidak terjerumus dalam hal-hal yang negatif.
Adapun menurut Jamal Ma'mur Asmani (2012:106) kenakalan-kenakalan peserta didik di sekolah diantaranya: Kesatu rambut panjang bagi siswa putra, walaupun tidak terlalu mengganggu namun siswa putra dengan rambut panjang cenderung tidak rapi dan menjunjukan adanya ketidaksiplinan. Berdasarkan catatan yang terdapat di bimbingan konseling terlihat 45 peserta didik laki-laki yang berambut panjang, namun tidak hanya itu peneliti pun melihat secara langsung banyak peserta didik laki-laki berambut panjang di MTs Al-Khairiyah Kepandean.

Kedua merokok, merokok kini seolah-olah sudah menjadi salah satu brand image dari remaja. Memang, tidak semua siswa yang merokok itu nakal, namun dampak jangka panjang dari aktivitas merokok itulah yang harus diperhatikan. Berdasarkan pengamatan peneliti melihat adanya peserta didik yang merokok diwarung-warung depan sekolah ketika jam pelajaran berlangsung.

Ketiga berkelahi, perkelahian memang suatu hal yang biasa terjadi di kalangan siswa, mengingat emosi siswa yang belum stabil. Perkelahian selalu terjadi di MTs Al-Khairiyah Kepandean hal itu dapat ditunjukan dengan adanya. Keempat mencuri, kenakalan jenis ini lebih mengerikan lagi karena sudah 
berkenaan dengan pelanggaran terhadap hak-hak orang lain. Banyak siswa yang diketahui mencuri benda temannya atau orang lain karena berbagai sebab

Berdasarkan hasil wawancara kepada guru yang ada di MTs Al-khairiyah Kepandean, peserta didik yang pernah melakukan pencurian terhadap temannya sendiri hanya beralasan iseng dan benda yang ia curi pun hanya alat-alat tulis berupa pulpen milik temannya sendiri.

Kelima pacaran, adalah ketertarikan antara seorang laki-laki dan perempuan yang dilandasi oleh apa yang disebut cinta, namun faktanya pacaran ini lebih banyak menjadi sumber malapetaka, karena berpotensi mendekatkan pada seks bebas. Meskipun sekolah MTs Al-Khairiyah Kepandean berbasis religius agama namun tidak dapat dipungkiri bahwa terdapat beberapa peserta didik yang memiliki keterkaitan antara peserta didik laki-laki dan perempuan.

Ketujuh sering bolos, banyak siswa yang suka membolos sekolah mereka berangkat pagi, tapi sudah keluar dari lingkungan sekolah ketika jam pelajaran belum berakhir. Membolos sekolah masih sering terjadi di sekolah MTs AlKhairiyah Kepandean, hal itu terlihat ketika peneliti ke sekolah terdapat peserta didik yang sedang dihukum dikarenakan membolos.
Kedepalan tidak disiplin, ketidaksiplinan anak didik ditunjukkan dengan sering masuk terlambat, tidak memakai sepatu, tidak memakai kaus kaki, berpakaian amburadul, logo sekolah tidak dipasang, dan lain-lain. Di MTs AlKhaiiryah Kepandean peserta didik tidak disiplin terlihat masih banyak peserta didik yang terlambat masuk sekolah.

Kesembilan bermain play station pada waktu jam pelajaran, saat ini play station bisa didapatkan dengan mudah meskipun tidak mampu membeli, para siswa bisa menyewa di rental-rental PS yang banyak dijumpai disekitar lingkungan sekolah. Hal ini tentu sangat mengganggu, karena banyak siswa yang kemudia membolos hanya untuk bermain play station. Hal ini terlihat pada saat-saat jam pelajaran berlangsung terdapat peserta didik MTs Al-Khairiyah Kepandean yang sedang bermain play station diwarung dekat dengan sekolah.

Kesepuluh mengotori kelas dan halaman sekolah, sekolah yang maju identikk dengan kebersihan dan kemauan untuk maju namun banyak anak didik yang suka mengotori kelas, sehingga kelas menjadi kumuh dan berbau tidak sedap. Berdasarkan hasil temuan, masih ada peserta didik di sekolah MTs AlKhairiyah Kepandean yang membuang sampah tidak pada tempatnya sehingga 
kelas dan halaman sekolah terihat tidak bersih.

Adapun berdasarkan hasil penelitian yang peneliti peroleh, bentuk kenakalankenakalan yang ada di MTs Al-Khairiyah Kepandean termasuk kedalam kenakalan yang bersifat a-moral dan a-sosial. Sebagaimana menurut Singgih D. Gunarso kenakalan yang bersifat a-moral dan a-sosial yaitu kenakalan yang tidak disebutkan dalam undang-undang sehingga tidak dapat atau sulit digolongkan sebagai pelanggaran hukum. Adapun bentuk kenakalan yang bersifat amoral yang ada di MTs Al-Khairiyah Kepandean antara lain, sebagai berikut: terlambat masuk sekolah, membuang sampah sembarangan, ramai dikelas ketika tidak ada gurunya, anak laki-laki berambut panjang, pacaran, membolos sekolah, membawa hp. Sedangkan bentuk kenakalan yang bersifat a-sosial yang ada di MTs Al-Khairiyah Kepandean yaitu: merokok diwarung sekitar sekolah, bermain play station pada saat jam pelajaran berlangsung, berkelahi dengan teman sebayanya.

Dengan ini kenakalan peserta didik di MTs Al-Khairiyah Kepandean dapat dikategorikan dalam kenakalan biasa, sebagaimana menurut Sunarwiyati $S$ dalam Jamal Ma'mur Asmani (2012:98) kenakalan biasa seperti: suka berkelahi, keluyuran, membolos sekolah, pergi dari rumah tanpa pamit, dan sebagainya.

Adapun faktor-faktor penyebab kenakalan peserta didik yang ada di MTs Al-Khairiyah Kepandean berdasarkan observasi dan wawancara disebabkan oleh: kurangnya pembinaan atau pembentukan hati nurani, pergaulan antar teman sebayanya yang dengan mudah mempengaruhi peserta didik lainnya untuk melakukan kenakalan, lingkungan sekitar sekolah yang banyak terdapat warung-warung, kurangnya perhatian orang tua kepada anaknya.

Maka faktor-faktor penyebab kenakalan peserta didik yang ada di MTs Al-Khairiyah Kepandean dapat dikategorikan berasal dari dalam diri dan luar peserta didik, sebagaimana menurut Soeparwoto, dkk, (2007: 212) faktor penyebab kenakalan dari dalam peserta didik, antara lain: Kurangnya penyaluran emosi, kelemahan dalam pengendalian dorongan - dorongan dan kecenderungannya, kegagalan prestasi sekolah atau pergaulan, kurangnya dalam pembentukan hati nurani. Dan faktor dari luar peserta didik, yaitu: faktor keluarga dan masyarakat. Dalam menekan kenakalan peserta didik perlu adanya upaya untuk mengatasinya. Upaya mengatasi kenakalan peserta didik dilakukan secara tindakan preventif. 
Tindakan preventif yakni segala tindakan yang mencegah timbulnya kenakalankenakalan (Gunarsa, 2009: 143-144). Tindakan preventif untuk mencegah kenalan peserta didik dapat dibedakan menjadi dua yaitu:

Pertama, usaha pencegahan timbulnya kenakalan peserta didik secara umum yakni berusaha mengenal dan mengetahui ciri umum dan khas peserta didik, mengetahui kesulitan-kesulitan yang secara umum dialami oleh peserta didik, dan usaha pembinaan peserta didik. Berdasarkan hasil observasi guru Pendidikan Pancasila dan Kewarganegaraan di MTs Al-Khairiyah Kepandean sering melakukan pembinaan kepada peserta didik baik itu didalam atau diluar kelas dengan cara menasehtinya.

Kedua, usaha pencegahan timbulnya kenakalan peserta didik secara khusus di sekolah, pendidikan mental ini khususnya dilakukan oleh guru pembimbing bersama para pendidik lainnya. Berdasarkan observasi di MTs Al-Khairiyah Kepandean guru Pendidikan Pancasila dan Kewarganegaraan selalu berkerjasama dengan guru bimbingan konseling, namun dikarenakan guru bimbingan konseling di MTs Al-Khairiyah Kepandean menjabat sebagai kepala sekolah disekolah yang lain sehingga membuat kurang efektifnya bimbingan mengenai pendidikan mental yang dilakukan oleh guru bimbingan konseling, maka untuk setiap harinya bimbingan pendidikan mental itu selalu diberikan oleh guru Pendidikan Pancasila dan Kewarganegaraan.

Adapun hambatan guru Pendidikan Pancasila dan Kewarganegaraan dalam mengatasi kenakalan peserta didik di MTs Al-Khairiyah Kepandean yang ditemukan di lapangan adalah disebabkan oleh terbatasnya waktu guru Pendidikan Pancasila dan Kewarganegaraan dalam membina atau mengarahkan peserta didik, selain itu lingkungan luar sekolah MTs Al-Khairiyah Kepandean juga turut menjadi pengaruh dalam mengatasi kenakalan peserta didik, salah satunya adalah terdapat banyak warung-warung yang dijadikan tempat berkumpul siswa saat membolos dimana para pemilik warung kurang memberikan perhatian terhadap peserta didik yang membolos, merokok, pacaran dan bentuk kenekalan lainnya. Hambatan lainnya bersumber dari dukungan pihak keluarga atau orang tua peserta didik, hal ini dapat dilihat saat orang tua atau wali yang tidak memenuhi panggilan pihak sekolah saat peserta didik mendapatkan peringatan dari sekolah sehingga efek jera kurang dirasakan oleh peserta didik, serta sikap peserta didik yang kadang bersikap acuh saat dinasihati 
oleh guru Pendidikan Pancasila dan Kewarganegaraan.

Hambatan yang disebabkan oleh dari guru itu sendiri merupakan salah satu faktor karakteristik seorang guru. Faktor karakteristik guru yang dapat mempengaruhi dalam pembentukan kepribadian dan kedisiplinan siswa dikemukakan oleh Muhammad Surya (2013: 103) bahwa "dalam proses belajar mengajar, guru memegang peranan penting sebagai mediator dalam belajar, artinya guru sebagai peranan dalam usaha memperoleh perubahan tingkah laku siswa." Berdasarkan hasil wawancara hal ini terlihat dari segi waktu yang sangat terbatas untuk guru Pendidikan Pancasila dan Kewarganegaraan di MTs AlKhairiyah Kepandean untuk melakukan pembinaan atau memberikan nasihatnasihat kepada peserta didik yang melakukan kenakalan untuk memperoleh perubahan tingah lakunya agar tidak mengulangi kenakalannya tersebut.

Guru Pendidikan Pancasila dan Kewarganegaraan dalam mengatasi kenakalan peserta didik di MTs AlKhairiyah Kepandean tentu mengalami adanya suatu hambatan. Sebagaimana yang dikemukakan oleh W.A Garungan (1986: 180) faktor penghambat dalam upaya mengatasi kenakalan disekolah, antara lain: Kesatu, faktor lingkungan keluarga merupakan kelompok sosial pertama dalam kehidupan manusia, berbagai peranan interaksi sosial dalam keluarga mennetukan tingkahlakunya terhadap orang lain di luar keluarga. Berdasarkan observasi di MTs AlKhairiyah Kepandean faktor keluarga tentu menghambat guru Pendidikan Pancasila dan Kewarganegaran dalam mengatasi kenakalan peserta didik, terlihat ketika peserta didik melakukan kenakalan dan mengharuskan pihak keluarga ke sekolah namun pihak keluarga tidak memenuhi panggilan ke sekolah.

Kedua, faktor lingkungan masyarakat yang merupakan tempat manusia berinteraski dengan manusia lainnya secara lebih luas. Berdasarkan pengamatan faktor lingkungan masyarakat tentu menghambat guru Pendidikan Pancasila dan Kewarganegaran dalam mengatasi kenakalan peserta didik di MTs Al-Khairiyah Kepandean, terlihat dengan adanya warung-warung yang berada disekitaran luar sekolah, pergaulan teman sebayanya yang sangat mudah mempengaruhi peserta didik lainnya untuk melakukan kenakalan.

Namun, tidak hanya itu faktor penghambat lainnya yaitu dari segi waktu yang sangat terbatas untuk guru Pendidikan Pancasila dan 
Kewarganegaran itu sendiri dalam menasehati atau memberi bimbingan kepada peserta didik untuk selalu manaati aturan-aturan disekolah MTs AlKhairiyah Kepandean dan tidak mengulangi kenakalan-kenakalan, dan belum adanya sanksi atau hukuman yang diberikan oleh pihak sekolah yang tegas kepada peserta didik yang melakukan kenakalan.

Adapun dari banyaknya hambatanhambatan dalam mengatasi kenakalan peserta didik, tentu guru Pendidikan Paancasila dan Kewarganegaraan mempunyai cara alternatif sendiri untuk mengatasi hambatan tersebut diantaranya, sebagai berikut: Kesatu, memberikan bimbingan atau arahan-arahan disela-sela penyampaian materi belajar pada saat proses belajar mengajar berlangsung. Kedua, mendatangi langsung rumah pihak orang tua peserta didik yang tidak memenuhi panggilan ke sekolah terkait masalah kenakalan anaknya. Ketiga, memberikan arahan-arahan kepada peserta didik untuk bergaul dengan teman yang baik. Keempat, memberikan perhatian khusus kepada peserta didik yang melakukan kenakalan-kenakalan.

\section{KESIMPULAN}

Berdasarkan hasil penelitian yang berjudul "Peran Guru Pendidikan
Pancasila dan Kewarganegaraan dalam Mengatasi Kenakalan Peserta Didik di MTs Al-Khairiyah Kepandean" maka dapat diambil kesimpulan sebagai berikut:

1. Peran guru Pendidikan Pancasila dan Kewarganegaraan dalam mengatasi kenakalan peserta didik dilakukan melalui sebagaimana peran nya, yaitu: Kesatu, peran sebagai pembimbing. Kedua, peran sebagai agen moral Ketiga, peran sebagai komunikator. Keempat, peran sebagai model.

2. Bentuk-bentuk kenakalan peserta didik di MTs Al-Khairiyah Kepandean termasuk kedalam kenakalan yang bersifat a-moral dan a-sosial Kenakalan yang bersifat a-moral, dan dapat dikategorikan dalam kenakalan ringan.

3. Hambatan guru Pendidikan Pancasila dan Kewarganegaraan dalam mengatasi kenakalan peserta didik, antara lain: Keterbatasan waktu pembinaan atau bimbingan kepada peserta didik, lingkungan sekolah yang terdapat warung-warung, pergaulan teman sebayanya, belum adanya sanksi yang tegas, pihak orang tua peserta didik yang tidak memenuhi panggilan sekolah. 


\section{DAFTAR PUSTAKA}

A. Buku

Arikunto, S. (2006). Prosedur Penelitian Suatu Pendekatan Praktek. Jakarta: Rineka Cipta.

Asmani, J. M. (2012). Kiat Mengatasi Kenakalan Remaja di Sekolah. Jogjakarta: Bukubiru.

Kartono, K. (2010). Patologi Sosial 2 Kenakalan Remaja. Jakarta: Grafindo Persada.

Moleong, L. (2014). Metodologi Penelitian Kualitatif. Bandung: PT Remaja Rosdakarya.

Mulyasa, E. (2015). Menjadi Guru Profesional. Bandung: Remaja Rosdakarya.

Soeparwoto, d. (2007). Psikologi Perkembangan. Semarang: UPT UNNES PRESS.

Suharsaputra, U. (2014). Metode Penelitian Kualitatif. Bandung: PT Refika Aditama.

Supardi. (2014). Kinerja Guru. Jakarta: Rajawali Pers.

Gunarsa, Y. S. (2009). Psikologi Remaja. Jakarta: PT BPK Gunung Mulia.

Hamalik. (2008). Kurikulum dan Pembelajaran. Jakarta: Bumi Aksara.

Gerungan, W. A. (2009). Psikologi Sosial. Bandung: PT Refika Aditama.

Surya, M. (2013). Psikologi Guru Konsep dan Aplikasi dari Guru, untuk Guru. Bandung: Alfabeta.

Djhairi, A. K. (2002). Dasar Umum Metodologi Pengajaran Pendidikan Nilai Moral. Bandung:
B. Perundang-Undangan

Undang-Undang Nomor 14 Tahun 2005 tentang Guru dan Dosen.

Undang-Undang Nomor 20 Tahun 2003 tentang Sistem Pendidikan Nasional.

Peraturan Pemerintah Nomor 32 Tahun 2013 tentang Perubahan Standar Nasional Pendididkan. Lab. Pengajaran PMP-IKIP Bandung. 